\title{
UNDERSTANDING THE INFORMAL PUBLIC TRANSPORT PRESENCE ALONG THE MINTAL- TUGBOK-CALINAN ROUTE IN DAVAO CITY, PHILIPPINES: AN EXPLORATORY STUDY
}

\section{Introduction}

\author{
By Marie Danielle GUILLEN**,Haruo \\ ISHIDA $* * *$ Naohisa OKAMOTO*** Morito \\ TSUTSUMI*** and Ayako TANIGUCHI***
}

Buses and taxis are traditionally part of formal public transport modes seen in most developed countries. On the other hand, in most cities of developing countries like the Philippines, informal motor vehicle- based public transport modes are also observed. In this paper, informal transport mode is defined as road-based motor vehicle, usually designed as low occupancy vehicle and is also often known as paratransit ${ }^{1)}$. Some are not even fully and/or legally bounded by national policies. They are usually privately operated and can be considered as a small-scale enterprise or means of self-employment. In some instances, they also lack the official and necessary credentials. There are many issues associated with road-based informal public transport services. The positive ones involve that of extensive network coverage, flexibility, availability and affordability. On the other hand, the negative issues concerning safety, noise and pollution are also commonly reported in most literature. Thus, it is important to understand the presence of informal public transport from a holistic planning perspective noting its differences with the formal modes as well as the role of key stakeholders such as the local government units, the supply-side (operator-drivers) and the demandside or the public transport user.

A wide variation of motor vehicle- based public transportation in the forms of public utility jeepneys (PUJs), tricycles (motorcycles with side-cabs) as well as an emerging very informal mode called "habalhabal" (or motorcycle taxis) is commonly found in Davao City. The city being the regional center for Davao Region in Southern Philippines is considered a business, investment and tourism hub. Interestingly, the increasing presence of informal public transport is contrary to the projected transportation system in 1981 . Based from the survey it conducted, the study especially recommended the introduction of city bus by year 2000 given the projected rapid increase in medium term length demand as well as the development of rail transit. ${ }^{2)}$ However, at present, the buses which are use specifically for city travel can only be found in one route, that is, from the central business district (CBD) to Calinan. The rest of the buses found in Davao City are use for inter-city or inter-provincial trips.

The importance of informal public transport sector has been recognized in many studies. It has also been noted in various policy recommendations. ${ }^{3)}$ Therefore, the need to rationally plan for and regulate transport in order to maximize its inherent economic advantages vis-à-vis formal transport becomes more convincing. Economic advantage in a sense, that its presence will not need huge investment for infrastructure. The objective is to make do with what is available in terms of providing transport mobility and accessibility as a service. The reality that it provides additional livelihood and employment opportunities for those who are in this sector should not be overlooked. However, there are limited studies on understanding informal roadbased public transport in comparison with the formal and legally accepted modes from a holistic perspective.

This paper aims to provide a holistic planning perspective by defining the road-based public transport sector through considering the policies and the public transport provider's situation as well as exploring demand-side modal behavior and comparing the informal public transport modes with the formal modes that are available for city public trips. The study area is particularly selected because this is the only route in Davao City where all types of road-based public transport modes can be observed. It hopes to understand the role of the different public transport modes among its key stakeholders. This paper, most specifically, look at the institutional set-up/local government and the supply-side (transport associations, operators and/or drivers) and how it affects the public transport service in the study area.

\footnotetext{
*Keywords: informal public transport, public transport, holistic planning, key stakeholders

** Non- member of JSCE, Graduate Student, Graduate School of Systems Information Engineering, University of Tsukuba (Tennodai 1-1-1, Tsukuba, Japan, TELEFAX +29-853-5591)

*** Member of JSCE, Dr.Eng., Graduate School of Systems Information Engineering, University of Tsukuba (Tennodai 1-1-1, Tsukuba, Japan, TELEFAX+29-853-5591)
} 
A review of the past and the present national and local policies as well as results of in-depth interviews is presented. Likewise, preliminary result of small-scale household and trip information survey is shown to give an overview on the service of each public transport modes.

\section{Research Framework and Data Collection}

In order to have a holistic understanding of the informal public transport service, comparison of the different public transport modes available in the area is made. Key stakeholders that include the policy-side and the institutional set-up (local and national government, supply (operators/drivers) and the demand or user-side were investigated. The policies and institutional dimension and the public transport supply sector are given special attention in this paper.

Figure 1 showed the research framework used in this paper:
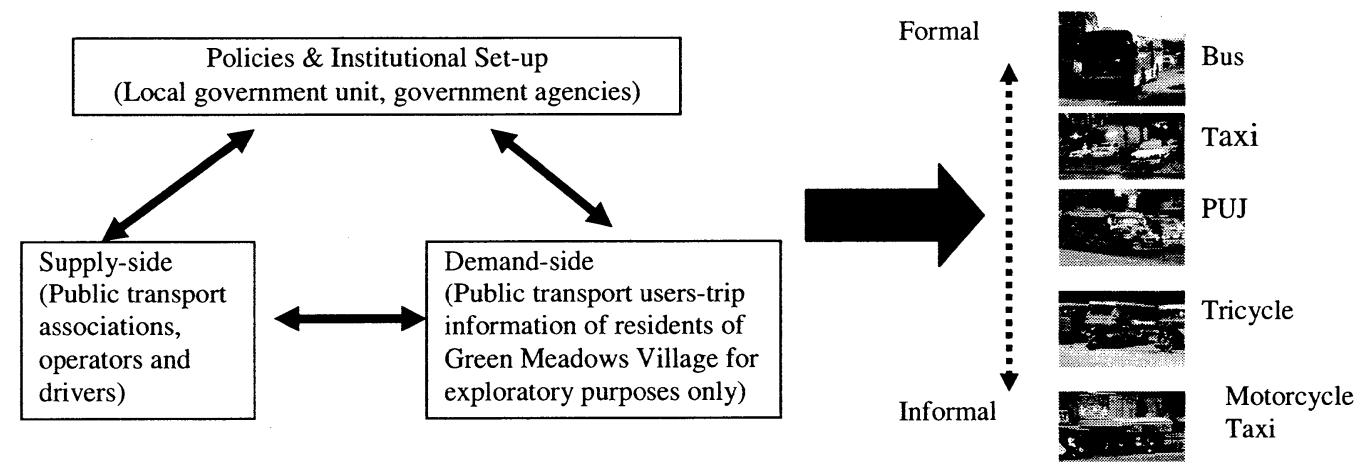

Figure1. Research Framework

The illustrated research framework (Figure 1) is an attempt to show the relationships (the arrows) of each stakeholder (the boxes represent policies and institutional set-up, supply-side and demand-side) with and among each other and how this affects the classification of the road-based public transport system in the study area. This paper assumes that each stakeholder affects the other and vice-versa (as indicated in the arrow directions).The assumptions as well as way of collecting information for each stakeholder as well as the over-all inter-relationships are discussed as follows.

\section{(1) Policies and Institutional Set-up}

The study assumes that there are policy and implementation issues that need to be thoroughly understood in order to fully address the related problems of the road-based public transport system. It further assumes that it can also be a factor in the emergence of some type of informal public transport mode. Documentary review of available records of policies at national and local level was undertaken in order to determine the historical policy time-line and development of each mode. In-depth interviews were carried out with the key local government and public transport agency officials.

$$
\text { Supply-side }
$$

It is also assumed that public transport providers are flexible and can supply the immediate needs of the community. Moreover, it is hypothesized that since public transport sector is provided by private individuals or corporation, there are some work and vehicle related concerns that are not fully addressed by existing regulations. In the absence of accurate and complete government records in getting operators and drivers' information, an ocular inspection was conducted. Leaders of public transport associations were initially interviewed. Conduct of public transport operation survey was done among operators, drivers, operators- 
drivers who are available at that time in public transport terminals or waiting stops of each mode along the identified study area.

Demand-side

The survey study assumes that even members of middle-class community are informal public transport users and that the younger population patronizes informal public transport modes like MC tricycles or "habal-habal".

To address the demand-side perspective, a middle-class residential area in a baranggay (the smallest local government unit in the Philippines) located along the Mintal-Tugbok-Calinan route was selected for the conduct of household information as well as trip information survey. Trip information survey is for household members aged 12 years old and older. This is done to explore and confirm their use of the different public transport modes.

A small-scale survey to $10 \%$ of the estimated households in the Green Meadows was selected at random for this exploratory study. Household members whose age is 12 years old and older were asked of their one day trip information.

\section{Conduct of interview and preliminary survey was held from January-February 2006.}

\section{The Inter-relationships among stakeholders}

At present, there are many policies enacted in the Philippines concerning the regulation of road-based public transport services. However, there are still questions on how to consider the continuous presence and or proliferation of the low-occupancy type of road-based public transport modes given some of the reported associated issues such as noise and pollution. Classification and definition of the available public transport modes using the formal-informal continuum. ${ }^{1)}$ is provided by having a comprehensive review of transport policies as well as the associated policies and its implementation with regards to using the vehicle unit as a public transport mode and understanding the situation of the providers or the drivers. This policy review is then related to the actual situation of the different public transport service providers: vehicle owners and drivers (the supply-side) in terms of management, working condition, vehicle maintenance and operating characteristics and are assessed accordingly. The level of public transport service and actual demand in the selected study area is also explored. And this is compared with the public service policy regulatory goals of providing a safe and efficient public transport mode in the area.

This paper assumes that informal modes continue to provide the unattended public transport demand. Informal mode vehicle are usually smaller in size and is designed as low-occupancy vehicle. Given this design, it can easily be filled up and can provide more trips. It is also assumed that informal mode providers have their internal management system. Another hypothesis is that informal public transport provision is a low-risk business with predictable revenue but hidden costs (vehicle and driver-related) are actually unaccounted. Moreover, policy regulatory and implementation is not strict in the area under study and public as well as public transport provider's needs are not always accounted for.

\section{The Study Area}

Compared to Metro Manila, the capital of the Philippines and the other metropolitan cities, Davao City is relatively young city. It has both the urban and rural population, so it tends to encounter problem ranging from lack of transport services to traffic congestion at the central business district (CBD). This is attributed to concentrated population and increasing motor vehicle ownership in the urban areas while in rural areas, the problem is due to poor road condition and road availability ${ }^{4}$.

Davao City is in the southern part of the Philippines, specifically in Southern Mindanao. It is the gateway to the Philippine South and has regular air, sea and land linkages to major points of the country. It is 
1hour and 40 minutes by plane from Metro Manila. It is bounded by the province of Davao del Norte, Davao del Sur and partly in the East, it faces the expanse of the Davao Gulf and the Island Garden City of Samal. It is considered to be the largest city in terms of land area at 2,443.61sq.km. It is divided into 3 congressional districts, 180 baranggays (the smallest political villages) and seven (7) distinct settlement areas namely; the Poblacion (CBD) Toril, Mintal, Calinan, Panacan, Tibungco, Bunawan, and Lasang ${ }^{5)}$. In addition, settlement areas are also developing in the districts of Marilog and Paquibato. The proposed plans being followed for each settlement areas are shown in Figure 2:

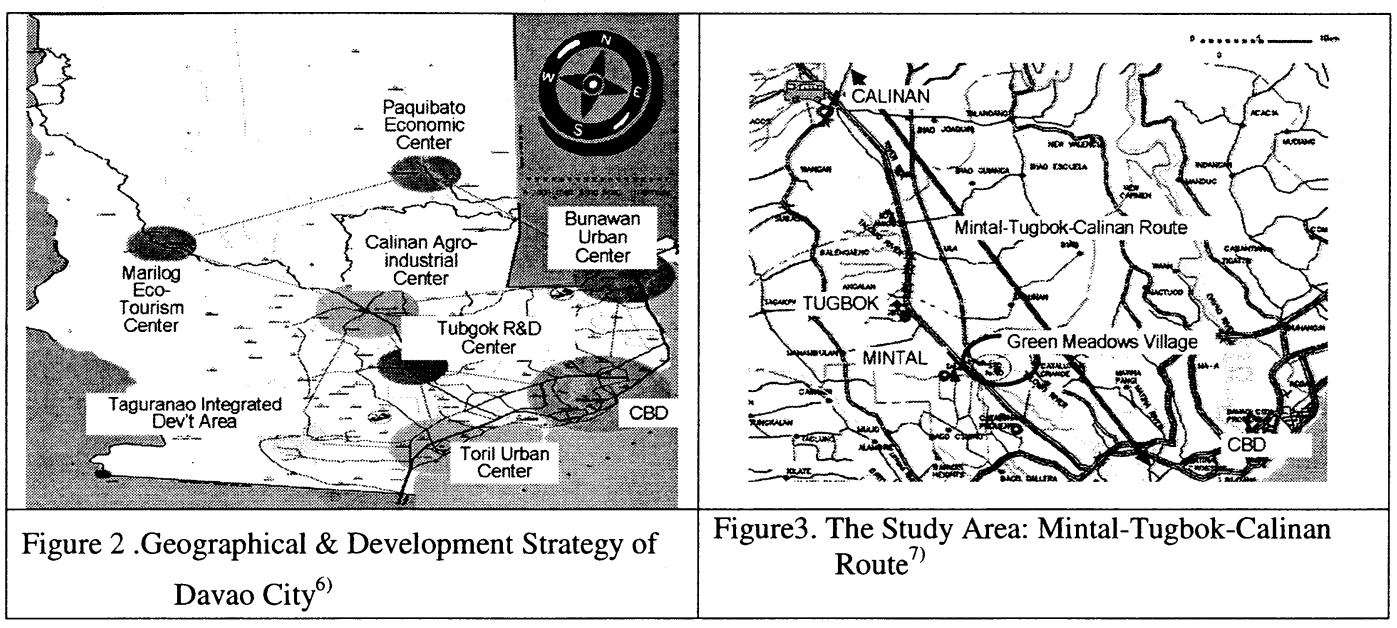

Almost $50 \%$ of the total land area is classified as timberland or forest. Agriculture utilizes around $43 \%$. About $10 \%$ of the total land area is the present built-up area which is used for residential, institutional, commercial and industrial purposes. The approved land-use plan built-up and settlement area is to cover $15 \%$ of the total land area. It is home to over a million people, with a growth rate of $2.83 \%$ and density of 540 persons per square kilometer. It has higher urban density however at 2,555 people per square kilometer. About $48 \%$ of total population is of working age ${ }^{8)}$.

\section{(1). Mintal-Tugbok-Calinan Route}

In order to get an understanding of the role of informal public transport sector, Mintal-Tugbok-Calinan Route (Figure 3) was chosen as the study site since this is the only route where the bus from the central business district (CBD) plies and where all other types of public transport modes available in the city can be observed. This area was part of the 1996-2021 spatial development plan of Davao City which suggest that Calinan be built as the new center for agriculture-based industrial activities and Mintal-Tugbok area as centre for technology, research and development programs. Moreover, this is also the area where most of the middle-class private residential areas/villages are located. An ocular inspection of the area verified the presence of buses, taxis, public utility jeepneys (PUJs), tricycles and motorcycle taxis plying along the route. There are two (2) PUJ Terminals (Mintal and Calinan) and one (1) bus terminal. In most entrances of residential villages, tricycles and motorcycle taxis waiting stops can be found.

\section{(2.) Green Meadows Village, Brgy. Sto.Nino}

The residential area selected was Green Meadows Village. It is a privately developed residential area with 1,360 housing units of mostly single-detached houses. An estimated $60 \%$ of the housing units are occupied by households belonging to the middle-class income bracket. It is the biggest housing village among the three (3) residential areas located in Barangay Sto.Nino and is around $20 \mathrm{~km}$ from the CBD, $10 \mathrm{~km}$ from Calinan (agribusiness center) and $3-5 \mathrm{~km}$ from most schools (elementary and highschool) and university campus (University of the Philippines and University of Southern Philippines). 


\section{Development Plan and Transport Policies in Davao City}

Having both urban and rural population, Davao City tends to encounter problem ranging from lack of transport services to traffic congestion at the CBD. In urban areas, this is attributed to concentrated population and increasing motor vehicles ownership while in rural areas, the problem is due to poor road condition and road availability ${ }^{9)}$.

Road network and highway in Davao City are classified according to the hierarchical level of government maintaining certain roads as follows:

Table 1. Road Hierarchy and Government Agencies-in-Charge

\begin{tabular}{|l|r|l|}
\hline Road Hierarchy & In Km & Agency in-charge of road maintenance \\
\hline National Road & 260 & Department of Public Works and Highways \\
\hline City Road & 626 & Office of City Engineer(local government unit) \\
\hline Baranggay Road & 839.7 & Baranggay and City government \\
\hline
\end{tabular}

Public transport is mainly served by land-based motor vehicles and is classified based on its registration as "for-hire" vehicle at the regional office of Land Transportation Office, Department of Transportation and Communication (DOTC).Public transport services are all provided by private owners/operators/individuals of different public transport modes and are regulated by Land Transportation Franchising and Regulatory Board (LTFRB) which issue franchises and other applications for land-based operators as well as regulates the fare rates of buses and PUJs. On the other hand, this is deregulated at the local city LTFRB for the tricycles. Except for the formal modes, most owners/drivers of public transport mode form associations based on the routes assigned to them. The Office of Transport Cooperatives, a support office under the DOTC, promotes transport cooperatives by encouraging associations to register as one. Based from interview with LTFRB officials, it was learned that there was a moratorium on the issuance of public transport franchise from 2002 because the system is being reviewed in Manila. And since then, there were no corrective measures done to respond to the increasing public transportation need of the city.

\section{The Local Public Transport System in Davao City and in the Study Area}

\section{(1) The Local Public Transport System in Davao City}

Davao city only have road-based public transport system. Buses, PUJs, taxis are regulated by the government thru Land Transportation Franchising Regional Board (LTFRB) office. Public Transport Franchises (territory, road-based) are awarded to any individual/s or enterprises that were able to fulfill the requirements. From Davao City's CBD, these modes use the Mintal-Tugbok Road, considered a national road to reach Calinan and vice versa. It is the only city bus route (CBD-Calinan) and its terminals are also privately operated by Annil Transport Company and are required to give commuter tickets to passengers upon payment of fare. Tricycles on the other hand are regulated by the Davao City Tricycle Franchise Regulation Board and are only allowed to use interior and minor roads within a barangay (the smallest political unit). Tricycle and pedicabs or bicycles with side-car are only allowed to service interior roads of residential areas and are banned in traversing along major roads and highways. Provincial buses are not allowed to operate within the CBD and have to utilize the government operated terminals (Davao City Overland Transport Terminal and Agdao Terminal) and some privately operated ones. Moreover, there are vans (also known as mega-taxis) for trips more than $30 \mathrm{kms}$ and areas or provinces outside Davao City and can sit from 10-12 passengers. Habal-habal emerged in latter part of 2002 and was initially observed in city outskirts and is considered illegal but is actually tolerated ${ }^{10)}$.

Historically, bus service were the first pre-war public transport use. This was first operated by the Davao Auto Bus Company with two standard size buses running around the city. No bus stops existed before and passenger can get at any point on the route. It was actually driven out of business by "auto-calesas" (ACs) or motorized calesas in 1951. The word "calesa" refers to the 2 passenger horse carriages which were imported from Europe, during Spanish rule. They look like mini-jeepneys and its service routes are designated and limited to the City boundary of Davao. ACs was engaged in short distance trips within the downtown area and performs similar function in the CBD. It was reported that in the 1960's, a large number of ACs were 
brought to Davao from Cebu City, where ACs were banned in an attempt to achieve coercive replacement of ACs with PUJs. It was in the 1970's when the ACs population decrease and was replaced by the PUJs. Tricycles, on that other hand, replaced "pedicabs" in the 1950s. These were revived in the 1980s at the time of oil crisis in the region. However, the operation of "pedicabs" didn't last since a local policy was enacted to ban its operation in late $1990 \mathrm{~s}^{11)}$

PUJs are generally used for short and even long-distance trips. In creating the jeepney, the Filipinos adopted and modified it to suit their own needs. And even if it faces competition from other innovations, it remains popular in urban areas as well as in rural areas where it can handle a muddy track with ease. It is known to be the poor man's transport, versatile, durable and colorful reflecting a uniquely Asian country. At present, its engine is imported mostly from Japan, as "surplus" (or second-hand) but its body or chassis is designed by artistic Filipino auto builders who adorn it with variegated images. An average jeepney can typically sit $15-20$ adult passengers. However, in remote rural areas where transport is scarce, it is typically overloaded $^{12}$.

Tricycles replaced the "pedicabs" (basically a bicycle attached to a carriage made of tin or galvanized iron) in the late 1950's. A tricycle is a motorcycle with attached colorful side-cabs and that no other alterations were made to the unit's design and engine. Like the jeepneys in the 1970's, the motorized tricycles were also given licensed. Licenses were issued at the national level registration system, formerly known as the Bureau of Transportation (BOT). They operated on local roads with neighboring areas offering local trips and feeder connections to buses and jeepneys. They were eventually removed in the main roads (except when no alternatives existed) since they did not mix with other vehicles due to its speed capabilities (cruising $20 \mathrm{kph}$ and maximum speed of $35 \mathrm{kph}$ ). It has lower acceleration power and has been cited as the cause of traffic delays and congestion ${ }^{133}$.

On the other hand, as previously mentioned, "Habal-habal",a local dialect used to identify motorcycle taxis or motorcycles "for hire" which means to sit close to each other has just recently emerged Aside from driver, there are at least one to three passengers who sit behind the driver and is the most recent phenomenon in the city. The presence of this mode is attributed to the gap in the public transport supply in some areas given the public transport franchise moratorium imposed in 2002.

Among the different public transport service modes regulated, survey conducted show that among public transport service drivers, only drivers of bus and of some big taxi companies follow Philippine labor and employment policies since drivers have regular monthly wages aside from certain percentage of their bus driving earnings and benefits such as Social Security System (SSS), Phil. Health etc. Moreover, in the labor data, only those enterprises with more than 4 persons employed are registered. Informal modes are usually driven by its owner and if not, employ 1-2 drivers. Strict implementation of labor code policies are not enforced among PUJs, tricycles and MC taxis since most often, drivers are also the owners, or if not, only verbal arrangements exist. In a way, this makes the PUJ and tricycles belong to the more informal mode continuum.

\section{(2) Local transport policy and implementing units of Davao City}

There are two major organizations responsible in overseeing and managing the traffic situation especially at the CBD area, namely: the Traffic Management and Control Board (TMCB) and the Traffic Management Center (TMC).

The TMCB was created by Executive Order No. 15 Series of 1988 as an institutional response to Davao City's growing vehicular and pedestrian traffic arising from street congestion and obstructions to ensure public order and safety.

The 1994 amendment prompted the creation of the TMC under the immediate and direct supervision of the Board to assist it in the performance of its functions and related sectoral concerns, as well as provide technical services including secretariat work for the Board. It is lodged and /or stationed in the Office of the City Planning and Development Coordinator. The office head is the designated Project Coordinator of the Unit. The office is closely assisted by the following offices: (a) City Engineer's Office, b) LTO, regional 
office (c) Department of Public Works and Highways (DPWH), Regional and District Offices, (d) Metropolitan District Command (METRODISCOM) Traffic Bureau, (e) Highway Patrol Group, (f) City Mayor's Office.

The Amended Executive Order on the TMCB also mandated the formation of sectoral or functional subunits in the field of (a) planning and engineering, (b) education, (c) enforcement, and (d) such other sectoral concerns as the Board may deem fit and adequate to achieve its targets and concerns.

It was in 1994 when the city's "Hapsay Dalan" Project which was considered an epitome of fine transportation planning, was institutionalized through the Sanggunian Panlungsod Resolution 789. The Operation Hapsay Dalan Committee monitors the management of traffic experiments being conducted by the Traffic Division along main streets.

One other mandate of the TMCB was to "promptly undertake a vigorous, multi-sectoral education and information campaign of all relevant information relative to any transport and traffic innovations and related activities. ${ }^{14)}$ This was partly been responsible for the removal of "pedicabs" and promotion of tricycles in feeder roads.

\section{(3) Public Transport Modes from City Proper (CBD) to Mintal-Tugbok-Calinan}

Using the formal-informal mode continuum, buses are considered formal modes since they are regulated and bus drivers are usually employed by big private transport enterprise. PUJs and tricycle fall close to informal modes since they are legally accepted and are regulated by the government but its drivers are usually counted as self-employed individuals and do not get fixed salary but dependent on the number of passengers they have. "Habal-habal" or motorcycle taxis are informal modes since they are not legally accepted.

The public transport modes available in the study area as well as the level of service are provided in the following table 2 .

Table 2. Service Level of Public Transport Modes available for the Mintal-Tugbok-Calinan Route

\begin{tabular}{|c|c|c|c|c|}
\hline & Bus & PUJ & Tricycle & MC Taxis \\
\hline Nos. of units & 12 & $100-110$ & $40-45$ & $\begin{array}{l}\text { Habal-habal or } \\
\text { taxis }\end{array}$ \\
\hline Coverage & $\begin{array}{l}\text { CBD- } \\
\text { Calinan } \\
(\sim 30 \mathrm{~km})\end{array}$ & $\begin{array}{l}\text { CBD-Calinan } \\
(\sim 30 \mathrm{~km})\end{array}$ & $\begin{array}{l}\text { Tertiary roads } \\
\text { only }(1-7 \mathrm{~km})\end{array}$ & Not applicable \\
\hline Vehicle design (seating capacity) & 46 & $21-23$ & 4 & 2 \\
\hline Peak hour capacity $\left(\mathrm{pax}^{*}\right)^{* *}$ & $80-100$ & $10-21 / 23$ & 4 & 4 \\
\hline Off peak hour capacity $(\text { pax })^{* *}$ & $8-25$ & $8-10$ & 2 & 1 \\
\hline Service Time $* *$ & & Varies from & Varies from & Varies from \\
\hline Weekday & $6 \mathrm{am}-11 \mathrm{pm}$ & $4 \mathrm{am}-11 \mathrm{pm}$ & 4am-12am & $5 \mathrm{am}-9 \mathrm{pm}$ \\
\hline Weekend & 7am-8pm & $6 \mathrm{am}-11 \mathrm{pm}$ & $5: 30-12 \mathrm{am}$ & 7am-6pm \\
\hline \multicolumn{5}{|l|}{ Ave. No. of trips/day** } \\
\hline Weekday & 8.4 & $4-6$ & 10 & 22 \\
\hline Weekend & 4.2 & $2-6$ & 10 & 18 \\
\hline
\end{tabular}

*Pax-passengers; $* *$ based on interviews with drivers

In the study area selected for the person-trip survey, taxis can be occasionally seen waiting in front of the village entrance. Since taxi's operating characteristic is distinctively very different from other modes, its level of service characteristic is not included here. All modes have similar association-agreed operation's rule where in a driver can only leave the public transport terminal when all the seats are taken. Tricycles ( 4 passengers) and MC taxis (2 passengers) can leave even if the seats are not taken if the passengers volunteer to pay for the seats not taken. 
Except for the buses and taxis, which are considered formal modes, the other common feature of PUJs, tricycles and "habal-habal" is that drivers and or drivers/owners usually group themselves into transport associations (Table 3). Only those members of associations can use the terminals or stops and they take turns into getting passengers. According to the interview with bus and taxi drivers, they are not permitted to form or join any associations by their employers. While bus drivers tend to earn more, more drivers seems to make livelihood with less formal modes and earn almost the same as those in the formal sector having legislated minimum daily wage of PhP200.

Table 3. Fare Structure, Association Names, Nos. of Owners/Drivers and Estimated Daily Income

\begin{tabular}{|c|c|c|c|c|}
\hline Mode type & $\begin{array}{c}\text { Fare Structure } \\
\text { Fare/person } / 1^{\text {st }} \cdot \mathrm{km}\end{array}$ & $\begin{array}{l}\text { Owner/ } \\
\text { Associations }^{1}\end{array}$ & $\begin{array}{l}\text { Drivers/ } \\
\text { Operator-driver } \\
\text { Members }\end{array}$ & $\begin{array}{l}\text { *Ave. estimated } \\
\text { daily income } \\
(\mathrm{PhP})^{2}\end{array}$ \\
\hline Bus & $\mathrm{PhP} 7.50+\mathrm{PhP} 1 / 500 \mathrm{~m}$ & Annil Bus Transit & 12 & 608.4 \\
\hline PUJ & $\mathrm{PhP} 7.00+\mathrm{PhP} 1 / 500 \mathrm{~m}$ & $\begin{array}{l}\text { Tagakpan Drivers' } \\
\text { Association } \\
\text { Calinan Drivers/Operators } \\
\text { Association }\end{array}$ & 210 & 273.0 \\
\hline Taxi & $\begin{array}{r}\text { PhP25(non-aircon) } \\
\text { PhP30 (aircon) } \\
+\mathrm{PhP} 2 / 200 \mathrm{~m} \\
\end{array}$ & Not applicable & Not applicable & 225.0 \\
\hline Tricycles & $\begin{array}{r}\text { PhP5.00 (student) } \\
\text { PhP7.00 (adult) }\end{array}$ & $\begin{array}{l}\text { GMSTODA } \\
\text { (from survey study area } \\
\text { only) }\end{array}$ & 90 & 295.0 \\
\hline $\begin{array}{l}\text { Habal- } \\
\text { habal or } \\
\text { MC taxis }\end{array}$ & $\mathrm{PhP} 5.00^{3}$ & $\begin{array}{l}\text { Golden Showers Drivers } \\
\text { Association } \\
\text { SMMPP }\end{array}$ & 65 & 208.0 \\
\hline
\end{tabular}

Note: ${ }^{1}$ All public transport associations in the study area are private. All the buses plying in the area are owned by one private company.

${ }^{2} \mathrm{PhP} 1.00=$ Yen 2.17

${ }^{3}$ An exception since MC taxis is illegal. Transport fare is decided by association.

( $*$ Based from interview with drivers (bus $=5, \mathrm{PUJ}=7$,taxi=4,tricycles $=8, \mathrm{MCtaxi}=8$ ) available at site during interview time.)

In terms of working condition, most of the drivers work on extended hours on the road averaging 72-80 hours a week. The Philippine Labor standard is 40 hours a week. Except for one MC Taxi driver interviewed, almost all hold valid driver's license and that the more formal the transport mode is, the more experience the drivers are. Only those employed in the formal modes (buses) have accident insurance covered.

Table 4. Public Transport Service Operator/Driver and Vehicle Situation

\begin{tabular}{|l|r|r|r|}
\hline Mode & \multicolumn{1}{|l|}{$\begin{array}{l}\text { Ave. Dehicle Age (In years) } \\
\text { (years old) }\end{array}$} & $\begin{array}{l}\text { Ave.Driving Experience } \\
\text { (In Years) }\end{array}$ \\
\hline PUB & 12 & 53.2 & 9.6 \\
\hline Taxi & 5.3 & 41.67 & 5 \\
\hline PUJ & 7.4 & 46.25 & 23 \\
\hline Tricycles & 2.3 & 41.75 & 5.5 \\
\hline MC Taxi & 2.5 & 20.4 & $<1$ \\
\hline
\end{tabular}

Note: $n=$ nos. of drivers: nbus $=5 ; n$ taxi $=4 ; n P U J=7 ;$ ntricycle $=8, n$ MCtaxi $=8$

(4) The Formal-Informal Classification of Road-Based Public Transport Modes

The formal-informal continuum was used where in the different public transport modes are classified by assessing it based on its working condition ,operating classification and the involved policies. 
Buses and taxis are regarded formal modes because they are covered under the franchising regulation and that owners provide drivers the benefits specified in the Phil. Labor code.

PUJs and tricycles are also regulated but labor and working conditions are often overlooked. This is what makes them informal mode.

MC taxis by all accounts are considered informal mode since they are not following any of the policies.

\section{The Case of Green Meadows Village, Brgy. Sto.Nino, Davao City}

A small-scale household information survey was done at random to $10 \%$ of the estimated $60 \%$ households residing in Green Meadows Village. Out of these households, those, whose age is 12 years old and above were asked about their one day trip information. 81 households with 165 household members gave valid information. Only 89 of the household members made trips at the time of the interview.

Household information of preliminary survey shows that most belong to the $\mathrm{PhP} 8,001-\mathrm{PhP} 30,000$ level of income and that $57 \%$ of households own a motor vehicle. Trip information survey reveals that $72 \%$ of trips were made by public transport.

While this is not comparable in terms of survey sample and study area to that of the initial and only available 1979 Davao City wide person-trip survey, the preliminary survey results nonetheless provided a glimpse of the average middle-class present description of its trip through the modal share, trip composition and trip length.

Figure 4 below reveals that PUJs are the most often used public transport mode by residents of the area. Interestingly, for the "to school trip purpose" there's an almost equal modal share of tricycles, PUJs and habal-habal. The latter, the most informal one, is also mostly used for going to school and/or when the purpose is for socializing. It can be inferred by this result that students perhaps have other consideration in choosing the modes they will use for this purpose. Ironically, in all trip purpose, the bus shows a very low trip usage. In this case, it can be assume that from the supply-side there are very few buses (there are only 12 buses for this route) plying in this area, hence less service frequency. It is also important to note that among the many road-based public transport modes, only bus modes issue commuter tickets as proof of their transport fare. Taxis, PUJs, tricycles and MC taxis do not issue anything to show proof of transport fare payment. The share of other modes is bigger giving public transport users more options to use in their travels.

Figures 4 and 6 give the trip and modal split composition in terms of trip purpose

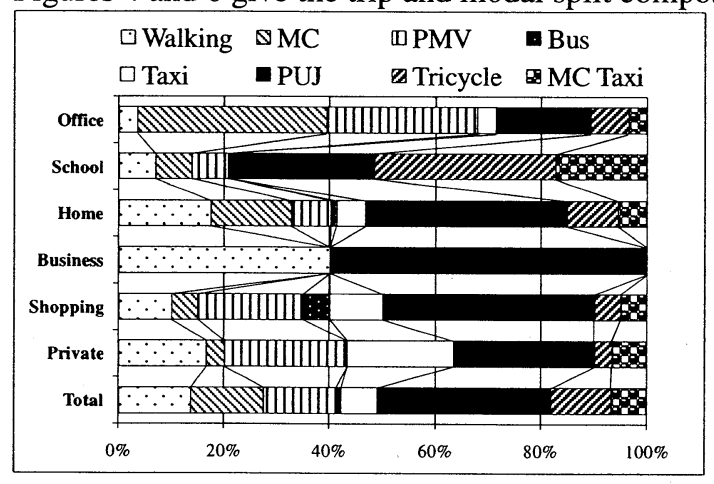

Figure 4. Green Meadows Village (study area) Trip Composition

Note: MC (motorcycle) PMV (private motor vehicle/car)

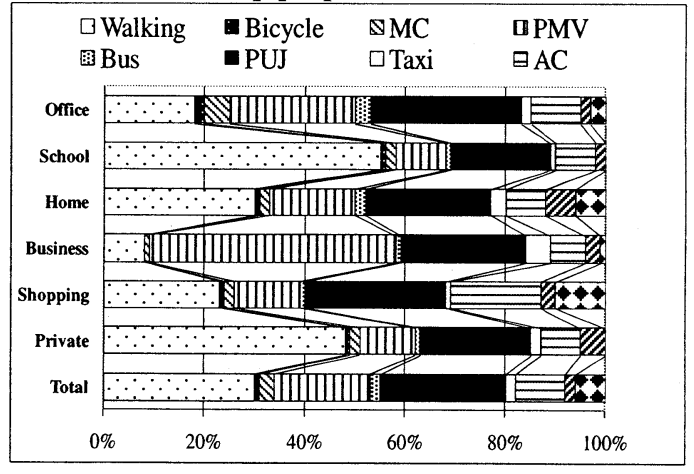

Figure 5. Davao City Trip Composition, $1979^{15)}$ Note: AC (Auto-calesa) Tri (Tricycle) 
The ocular inspection and survey confirmed that there was no available AC (auto-calesas) operating in the City. Figures 4 and 5 above revealed that there are no big changes in terms of the use of motor vehicles for public transport service. The change is in the type of available public transport mode, which at present is being replaced by the MC taxis. It is interesting that $\mathrm{MC}$ taxis are mostly use for school trips and can be inferred that it is mostly used by students. Perhaps, students are not really concern whether it is safe or not and may even think that riding one is in a way fashionable.

As shown in Figure 6 below, the implementation of city buses was one of the initial recommendations of the 1981 Davao City study. These initial survey findings in the Mintal-Tugbok-Calinan route confirm that PUJs are still the most common form of public transport mode used by residents of the area. Interestingly, as shown in Figure 7 there is an almost equal share of tricycle, PUJ and MC taxi or "habal-habal" use. For going to school and/or when the purpose is for socializing, the latter is mostly used. Another important dimension that should be taken note of is that MC taxis are mostly used for short-distance travel (Fig.7). It can be inferred that users recognized the danger of using the mode and thus use it only for short-distance travel. The bus on the other hand, shows a very low trip usage and can be assumed that this has something to do with the frequency since very few buses (only 12 buses) were plying in the area. The presence of different types of motor vehicles use for public transport service provides users more options in choosing the mode to use for their travels. Moreover, this exploratory investigation showed that even in a middle-class residential area, informal mode play a role in providing public transport service.

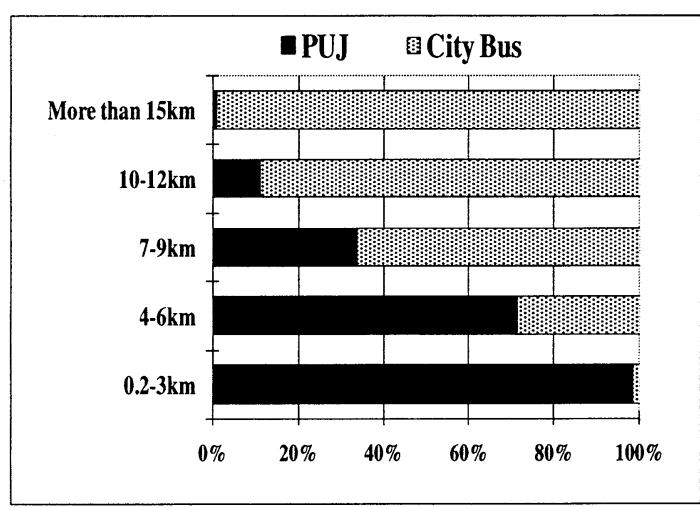

Figure 6. Davao City Projected modal share $(\%)$ of public transport mode in 2000 by trip length ${ }^{16}$

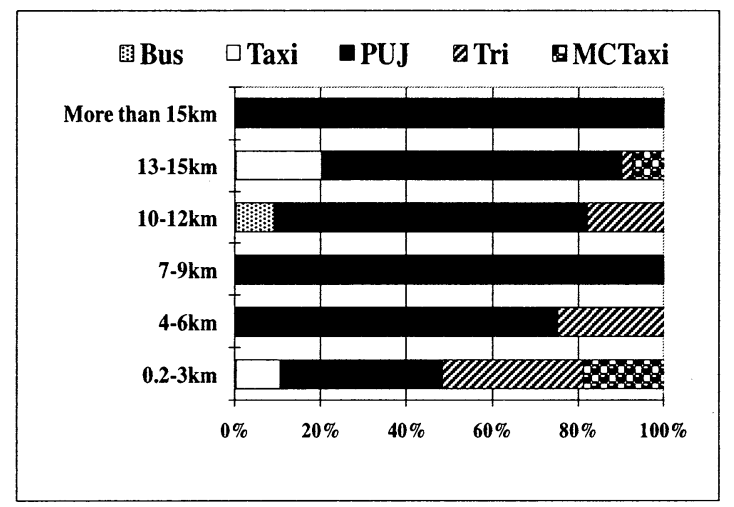

Figure 7. Green Meadows Village Modal share (\%) of public transport mode per trip length

Note: The numbers indicate the nos. of respondents taking the mode.

\section{Conclusion}

A holistic approach is important in order to understand the presence of informal public transport modes. In this paper, the role of major stakeholders is presented with special emphasis given on the institutional setup and the supply-side sector (public transport associations, operators/owners and/or drivers) is discussed.

In-depth interviews and documentary evidence revealed the role of some policies as well as institutional changes in the presence of public transport supply gap. For, example, the emergence of "habal-habal" is initially attributed to the nationwide moratorium on the issuance of public transport franchise by LTFRB in 2002. This cannot easily be corrected since the political and organizational changes should also be considered. In terms of institutional set-up, it seems that the issuance of public transport franchise is not coordinated at the local level and that public transport supply gaps are not easily addressed. Moreover, there are no accurate and available yearly data on the number of public transport modes plying on different routes.

Survey and in-depth interviews on the public transport supply sector presented interesting information on the nature of its organization. The presence of strong public transport association is the key feature of 
more informal modes like the PUJs, tricycles and "habal-habal". Aside from the organizational structure, public transport associations provide the needed discipline in taking turns to get passengers. Public transport associations act as its internal" police" or provides some sort of system among drivers. It provides some order and system so that all the members (drivers) benefit. The formal modes like buses and taxis are operated by a business sector and thus are not allowed to have associations. On the other hand for the informal modes, there are those who make public transport service supply as a livelihood and as an employment and/or both. The former means that it is operated like a business and has the capability to employ drivers. However, it is important to note that the cost of a bus unit as well as its administration cost such as the issuance of commuter tickets is also high. The survey showed that on a daily basis, the bus drivers earn more, however, those that belong to the more informal transport sector ("habal-habal") earn almost as same as those of the less informal modes (tricycles, PUJs) and are meeting the legislated minimum wage rate. It is also interesting to note that while MC taxis or "habal-habal" can technically ply anywhere, data on trip length shows that it is only use for short-distance trip which can mean that they most likely only operate within the baranggay and not in the CBD where most of the traffic enforcers are stationed. The study area is around $20 \mathrm{~km}$ away from the CBD. However, another important dimension revealed in this study is that of the labor and working conditions of those belonging in this sector. The investigation showed that the informal public transport drivers work beyond the labor standard set and do not have the same benefit as those in the formal sector. Related policies reviewed showed that there are no strict rules or regulations in hiring public utility drivers. It is important to consider that the plight of these drivers who are actually the ones responsible in providing the public transport service.

The small-scale household information and trip information survey in Green Meadows Village provided a preview of the present situation in the area. It confirmed the presence and the users of the different public transport modes available in the area. As previously mentioned in the research framework, this paper's emphasis is on the policies as well as institutional dimension and its relationship to supply-side. In the future, a more detailed trip demand analysis given the presence scenario should be done to provide stronger relationships with the other stakeholders. Moreover, at the supply side, the public transport quality of service must be considered and it is only then the appropriate policies can be recommended. Since the provision of road-based public transport service is privatized, it is also important to consider the plight of the vehicle owners, the cost of a unit as well as maintenance of the vehicle and also the drivers, who are actually the ones providing the public transport services.

Overall, even if this study is still at the exploratory stage, it presented a very brief holistic perspective to understand the presence of informal transport by accounting the role of each key stakeholder. It is important to consider the socio-economic, the political situation and the accompanying policies at the national and local level. Important attention should be directed towards good transport service quality, fair and equal employment and labor standards practice and better living environment.

Further directions of the study will involve conducting an evaluation of the quality of service of the different public transport modes and knowing how the residents (public transport users) assess their subjective and actual dependency to the different public transport mode available in the area. Aside from some "flaws" in enforcing policies and the need for supplying the unattended public transport service needs, informal modes presence can also be attributed to the fact that some people really use it. Most informal mode providers are actually familiar in the area and this might explain why they continue to proliferate too.

\section{Acknowledgements}

We wish to thank Prof. Sasaki, then a Visiting Professor from University of the Philippines- National Center for Transportation Studies who joined the authors in the conduct of ocular inspection and interview with local government officials and with public transportation association leaders in Davao City, Philippines in February 2006. 


\section{REFERENCES}

1) Cervero R. : Informal Transport in the Developing World, HABITAT, Naorobi, 2000

2) Japan International Cooperation Agency: Davao City Urban Transport cum Land use study-Final Report, Vol.1, p.37-42, 1981

3) World Bank, Sustainable Transport- Priorities for Policy Reform, Washington D.C., p.77, 1996

4) Office of the City Planning and Development Coordinator: Comprehensive Development Plan (19962021), Davao City, p.111, 2002

5) Office of the City Planning and Development Coordinator: Comprehensive Development Plan (19962021), Davao City, p.78-83, 2002

6) Office of the City Planning and Development Coordinator: Comprehensive Development Plan (19962021), Davao City, p.78-83, 2002

7) Business Reporter, Davao City, 2002

8) Official website of Davao City, http://www.davaocity.gov.ph Accessed on: 17 January 2007

9) UP National Center for Transportation Studies. Davao City Transportation Plan in CDRom, 2000

10) Public Information Office.' Habal-habal, Useful but Illegal", http://www.pia.gov.ph/default.asp?m=12\&fi=p040211.htm\&no=6 Accessed on 15 September 2004

11) Guillen, M.D, A Study on Development of Local Public Transport Policy: The Case of Tricycles and "Habal-habal" in Davao City, Philippines. Masters Thesis, Univesity of Tsukuba, 2004

12) University of Hawaii- Center for Southeast Asian Studies. "Remarkable Jeepneys in the Philippines", http://www.hawaii.edu/cps/jeepney.html Accessed on 13 July 2006

13) Guillen, M.D, A Study on Development of Local Public Transport Policy: The Case of Tricycles and "Habal-habal" in Davao City, Philippines. Masters Thesis, Univesity of Tsukuba, 2004

14) UP National Center for Transportation Studies. Davao City Transportation Plan in CDRom, 2000

15) Japan International Cooperation Agency: Davao City Urban Transport cum Land use study-Final Report, 1981

16) Japan International Cooperation Agency: Davao City Urban Transport cum Land use study-Final Report, 1981 


\title{
UNDERSTANDING THE INFORMAL PUBLIC TRANSPORT PRESENCE ALONG THE MINTAL-TUGBOK-CALINAN ROUTE IN DAVAO CITY, PHILIPPINES: AN EXPLORATORY STUDY
}

\author{
By Marie Danielle GUILLEN**,Haruo \\ ISHIDA***Naohisa OKAMOTO*** Morito \\ TSUTSUMI*** and Ayako TANIGUCHI***
}

Traditionally, buses and taxis are the legally- accepted road-based public transport modes. But in most developing countries, alternative types of public transport vehicles can be found. Informal public transport concept is adopted in this paper. Its importance has been widely recognized but limited studies on understanding it from a holistic perspective.

This paper attempts to understand the informal public transport mode from a holistic perspective by understanding the role of the different public transport modes (jeepneys, tricycles, motorcycle taxis) among its key stakeholders. Specifically, it investigates the local government side, its institutional set-up and the public transport supply sector.

\footnotetext{
ダバオ市ミンタル・トゥグボク・カリナン道路沿線における地域特有の公共交通サービスに関す る研究

$$
\text { マリーディニエルギリン・石田東生・岡本直久・堤盛人・谷口綾子 }
$$

現在バスやタクシーは、道路における公共交通手段として広く一般に受け入れられて いる。しかしながら、多くの発展途上国では、これらとは違った公共交通が見られ る。本稿では、このような地域特有の公共交通に焦点を当てる。これら地域特有公共 交通の重要性に関しては広く認識されているものの、それらの全容に関する研究はほ とんどない。そこで本稿では、様々な公共交通手段の役割を理解することによって、 途上国特有の公共交通システムのあり方に関する知見を得る。具体的には、地方政 府、法的周辺環境、公共交通の供給セクターに焦点を当てる。
} 